\title{
FLIPPING THE CLASSROOM REMOTELY: IMPLEMENTATION OF A FLIPPED CLASSROOM COURSE IN HIGHER EDUCATION DURING THE COVID-19 PANDEMIC
}

\author{
Thanassis Karalis ${ }^{\mathrm{i}}$, \\ Natassa Raikou \\ Laboratory of Pedagogical Research and Lifelong Education, \\ Department of Educational Science and Early Childhood Education, \\ University of Patras, \\ Greece
}

\begin{abstract}
:
In this article we present the results of a pilot implementation of the flipped classroom methodology during the second semester of the COVID-19 pandemic. We suggest the term Remote Flipped Classroom for the flipped classroom mode in online environments, especially in case of emergency. This implementation was carried out in a Department of Education at the University of Patras, Greece after the first semester and the initial familiarization of students with the new learning environments due to COVID-19 pandemic. The research data presented here lead us to the conclusion that both the traditional form of the flipped classroom and the remote flipped classroom may contribute to the teaching and learning in higher education, based on the role differentiation of instructors and students, to the promotion of active participation and engagement of students and to the improvement of the learning experiences they have.
\end{abstract}

Keywords: higher education pedagogy, flipped classroom, remote flipped classroom, COVID-19 pandemic

\section{Introduction}

Like all pandemics, COVID-19 pandemic, was initially considered as a major event, mostly regarding its health $\kappa \alpha$ เ sanitary dimensions, which calls for urgent solutions in order to facilitate the return to normality. Nevertheless, almost all pandemics, apart from their direct impact, also have long-term effects on many sectors of social and financial life and usually lead to changes and transformations of many activities. The COVID-19 pandemic significantly affected education systems worldwide, as it broke out almost simultaneously and the policy makers and educators were required to find quick and relatively reliable solutions for the restoration of the educational disruption. The

i Correspondence: email karalis@upatras.gr 
statement by the Director General of UNESCO, Audrey Azoulay in March 2020, right after the World Health Organization declared COVID-19 as a pandemic, is characteristic: "We are entering uncharted territory and working with countries to find hi-tech, low-tech and notech solutions to assure the continuity of learning." On April 3rd, 2020, UNESCO stated that almost 1.5 billion students (a percentage of $83.8 \%$ of the total) in 168 countries were kept out from educational institutions. It is the first pandemic from a historic point of view that has struck education so hard and the reason is that in the last sixty years education has been massified and more students than ever before are part of educational structures of all education modes and levels.

This paper shall outline an implementation of the flipped classroom in a Department of Education in Greece, in a course that was carried out totally in distant mode, and this is the reason we call this particular implementation remote flipped classroom, as it differs in this point from all implementations of flipped classroom methodology up until this point.

\section{COVID-19 pandemic and Flipped Classroom}

The University of Patras was among the first ones to implement the transition to online learning, already since the outbreak of the pandemic in the beginning of the spring semester of the academic year 2020-2021. The Department of Educational Science and Early Childhood Education, in almost ten days since the beginning of the first national lockdown, had completed the transition to online teaching for all its theoretical courses, while some laboratory courses and the practicum were provided with online simulations. According to the available research data, the students of the University in general (Karalis, 2020), and also those of the Department where the implementation of remote flipped classroom was carried out, were especially satisfied by the quick transition, and also by the quality of online teaching (Karalis \& Raikou, 2020; Raikou, Kaltsidis, Kedraka, \& Karalis, 2020), something rather important as during the same time the students were still suffering from psychological problems due to the quarantine (Konstantopoulou \& Raikou, 2020). A similar readiness was observed in almost all the universities in Greece, as it can be shown by the relevant researches (Charissi, Tympa, \& Karavida, 2020; Kamarianos, Adamopoulou, Lambropoulos, \& Stamelos, 2020).

Since, according to all data, the return to face-to-face teaching is near, in other words to what was referred to as normality during the crisis, we think it is necessary to highlight certain points of the experience of the pandemic and also some remarks on the return to what could be now called a new normality. The transition to online teaching, successful as it was, had some features which can not be overlooked when assessing the experience of the COVID-19 pandemic. This transition was carried out very fast and both the instructors and the students were forced to experience changes in their roles, or a transition to new roles, while the in-between period was extremely short (Pandya, Patterson, \& Yun Cho, 2021; Panther, Allee-Herndon, Perrotta, \& Cannon, 2021). All communication turned into two-dimensional from three-dimensional within just two 
weeks, body language from both sides of the screen was not easily decipherable, since faces and bodies had been "replaced" by squares on the screen (quite often black ones, due to the lack of camera among many students). This forced acquaintance with ICTs inevitably affected the day after and the new normality. An increased penetration of ICTs is expected to occur within the traditional academic environment, as well as a tendency for increased hybridness, i.e., a more intense osmosis of face-to-face education with online learning. Given that education is not always among the priorities of policy makers, the "temptation" to propose solutions in order to reduce the cost of education will be one of the main points of the debates on the day after. This will not necessarily lead to a dystopia where teachers and learners will only communicate from a distance, however, defending education in the field of higher education, entails the reflection both on the experience of the pandemic and on the traditional way of teaching. In other words, the arguments in favor of education in their form up until now, should not be generic, but rather specific, and they should aim at what could be really achieved by in-person teaching. This thread of documentation shall lead to the renewal of traditional teaching itself, with realistic arguments which will concern the reason they are really necessary, the different chances that are offered to teachers and students, leading to a new environment where teachers shall not be talking heads, i.e. reproducers of the educational material and students shall not be mere consumers of ready-made recipes. We believe that the Flipped Classroom will be one of the tools that will combine ICTs more effectively with a differentiated role on the part of teachers and a more active role of students.

The term flipped classroom (FC), especially for higher education, suggests a reversal of the traditional way of teaching, which consists mostly of the use of lecture in the classroom and then the assignment of homework to the students. In the approach of the FC, this logic is reversed, since the study of new content is carried out by students at home, mainly through studying videos and educational material which have been posted on repositories or systems of asynchronous education, while in the classroom it is expected to carry out more participatory activities, which promote the engagement of the students (such as individual or group projects, work in groups, debates). Through this intervention, not only a better understanding of the content is sought, but also the development of collateral skills on the part of the students (indicatively: critical thinking, argumentation, collaboration, creativity). Abeysereka \& Dawson (2014, p. 3), after referring to the seminal work by Baker and Strayer, define as the main characteristics of FC, a change in the use of time (both in the classroom and out-of-class), doing activities traditionally considered as "homework" in class and the opposite, in-class activities emphasizing active learning, peer learning, problem-solving, pre and post-class activities and the use of technology, especially videos. Finally, they define FC as "a set of pedagogical approaches that move from information and transmission-oriented teaching out of class, use class time for learning activities that are active and social and require students to complete all proposed activities (pre and post-class) to fully benefit from the work done in class". 
The characteristics and configurations mentioned by Abeyrereka \& Dawson provide us with a complete outline of the FC, yet we consider it necessary to refer to certain misconceptions regarding the FC that can be found in the scientific literature. Building a course on the logic of FC does not necessarily entail a system of asynchronous education or an LMS (Learning Management System), not even particularly advanced technological solutions, even if their existence can surely make the FC course more effective. Moreover, the mere upload of materials on a repository does not constitute an FC, unless it is accompanied with a differentiation of the classroom interventions and with studying instructions for the students. A crucial point for the FC is the complete change in what the instructor does in the classroom, the fact that s/he works more effectively with them, that $\mathrm{s} /$ he does not leave them alone with the educational material, that $\mathrm{s} /$ he uses more active and participatory teaching techniques which lead to the gradual increase in the responsibility of students to explore the content.

However, what happens in cases where due to a force majeure or by design (for example distance education courses) the existence of a classroom or an amphitheater is not possible? We suggest the term Remote Flipped Classroom (RFC) to describe a variation of the FC when the field of face-to-face application is a tool of synchronous education and not the traditional classroom education. A variation based on the exploitation of all the fundamental elements, characteristics and pedagogical principles to develop a more participatory, active and meaningful learning experience for students remotely. We shall expand on that subsequently, i.e. the experimental implementation of an RFC course during the COVID-19 pandemic, beginning from the detailed description of the main structures of the elements and pedagogical principles and citing detailed data on the assessment of its implementation subsequently. It should be noted that, even though there are references to the use of the FC model during the pandemic (Collado-Valero et al., 2021), and also research data which concern its potential (Lattore-Coscullela, et al., 2020), the literature review until today has not showcased a study that refers to the designing and evaluation of a specific course based on the FC during the COVID-19 pandemic.

\section{Description of the Course}

In every implementation and assessment of a FC course, we consider necessary to cite in detail all the design and structure data of the course, since it is the only way to clarify whether it is a flipped classroom and not just a simple substitute of the lecture by a repository, the way and extent to which activities were designed and implemented, that promote active participation and engagement of students, as well as the discipline or object of the course. All of the above are important in order to be aware of what exactly is evaluated and the perspectives of a more generalized implementation of the proposed solutions.

In this case, it was a course under the title "Higher Education Pedagogy" which was scheduled to be taught for the first time during the third year of studies at the 
Department of Educational Science and Early Childhood Education of the University of Patras. The University of Patras is one of the most well-known higher education institutions in Greece, having 35 departments in the wider region of Western Greece and more than 33,000 students. At the aforementioned Department, it was considered necessary to introduce a course which would concern an emerging field in the scope of the Sciences of Education, that of Teaching and Learning in Higher Education. The content of the course consisted of the following modules: Higher Education as learning environment, role and duties of university instructors, characteristics of students, adulthood, planning and evaluation of a higher education course, e-learning in higher education, development of critical thinking and creativity skills. It should be briefly noted that the modules which were included in the content of the course, such as the skill to be developed (e.g. cooperation, critical thinking), had been an object of investigation during the previous years (Raikou, Karalis, \& Ravanis, 2017; Liodaki \& Karalis, 2013; Raikou, 2012; Raikou \& Karalis, 2011, Karalis, Sotiropoulos, \& Kampeza, 2007). The course was integrated into the study program of the Department in the spring semester of the academic year 2019-2020 and it was scheduled to be taught in the winter semester of the following academic year.

At first, although there was a tendency to return to face-to-face teaching since the winter semester of the academic year 2020-2021, the course was designed as a "traditional" FC. It should be noted that the implementation of the FC is not particularly widespread among Greek higher education, since up until now only two cases of implementation are mentioned (Rakitzi, Botsoglou, \& Roussakis, 2020; Plota \& Karalis, 2019). Nevertheless, during the summer of 2020 it became apparent that the following academic semester would continue with online teaching. The instructors decided to turn all the face-to-face part of the course into online, yet maintaining the basic pedagogical principles that are mentioned for the face-to-face part of the FC as well. Therefore, the part of synchronous education (which, in this case, was the official software available at the University of Patras, i.e. Zoom), would every time include the minimum lecturing possible or no lecturing at all, mostly to respond to queries, and the three hours of the online teaching would be used for activities in which the students would participate. In this part of the course, the techniques used were discussion on a specific matter, work in groups (using the breakout rooms function of Zoom), debate, brainstorming (mostly with the use of chat), voting (using Zoom's internal tools or software that allows a better visualization of the results, such as Mendimeter), and case studies.

A significant point is the implementation of the above techniques in a new environment, both for the instructors and the students. This implementation should not be a mechanistic transfer of what takes place at in-person education, all educational techniques gain a different momentum at the online environment and some fundamental principles of adult education must be taken into consideration for their implementation. These principles of student-centered approach include issues, such as the promotion of an active participation of students, communication, collaboration, interaction, studentinstructor immediacy and intimacy (Pavlis-Korres, 2020; Pavlis-Korres, Karalis, 
Leftheriotou, \& Barriocanal, 2009, Karalis \& Koutsonikos, 2003). Designing the course, transforming it from FC to RFC and delivering it, was carried out with the two co-authors of the article serving as instructors, and each one of them coordinated specific modules, while co-teaching was used for some of the modules.

As already mentioned, the design of this particular course followed the logic of the FC, except for the fact that the face-to-face sessions in the classroom were replaced by online sessions through the asynchronous education software (Zoom). The software for asynchronous system used was the electronic classroom of the University of Patras. The courses last 13 weeks per semester in Greek universities and in this case the course was structured in ten weekly modules, as the first session concerned the introduction and explanation of the course conditions to the students, and the last two weeks the presentations of the assignments that had been completed by them within the framework of the continuous assessment that was applied.

As for the part of asynchronous education, the weekly studying was accompanied by a study guide, the importance of which had been explained to the students during the introductory session. In summary, the material of the asynchronous part included:

1) Videos by the instructors: 7 videos in total, with a duration of 3 hours and 47 minutes.

2) Videos from the Internet relevant to the content of the modules: 8 videos in total, with a duration of 3 hours and 15 minutes.

3) Powepoint presentations: 7 presentations with 84 slides in total.

4) Notes and educational material packages: 17 material packages, 287 pages in total.

5) 5 Quizzes, which were completed during weeks 1, 4, 5, 9 and 10.

6) 3 activities, i.e. short essays to further comment on the sessions.

7) Three quite long essays which served as the basis for the evaluation of the students. The essays had a modular form, they were assigned during weeks 2, 5 and 9 and concerned basic points of the content.

In summary, it could be argued that on average, the students before every session had to study 43 minutes of video, 9 slides of PowerPoint and 29 pages of educational material, while before every online lesson they had to complete either a quiz or a written assignment.

Regarding the synchronous part of the RFC, the following activities were noted in the instructors' calendar:

a) Interventions on the part of the instructors for the coordination of the courses, for the instructions of the assignments and any procedural issues (estimated to $25 \%$ of the total time depending on the structure of every session).

b) Assignments in groups using the breakout rooms function of Zoom (estimated to $25 \%$ of the total time).

c) Queries about everything that they had studied during the previous week using the asynchronous education system (15\% of the total time).

d) Discussion on the main point of the content ( $25 \%$ of the total time). 
e) Other activities ( $10 \%$ of the total time). This category also includes two lectures by invited professors of other universities.

\section{Assessment of the Course}

Before moving on to the analysis of the data concerning the assessment of the course, we consider necessary to clarify certain points regarding the participants and the tools which all the data were gathered with and which the assessment is based on. This particular course was an elective one and it is offered for selection during the third year of studies. 179 students opted for the course, however, not all of them attended it, since attending the elective courses in not obligatory. The students were given the opportunity for continuous assessment throughout the duration of the semester and were exempted from the obligation to participate in the final examination. In order to be exempted from the participation in the final examination, the following conditions had to apply:

a) Completing three assignments.

b) A brief presentation of the three assignments in the last two lessons (sessions) of the semester.

c) Participation in the activities and the quizzes.

d) Attending at least $80 \%$ of the sessions held through Zoom.

The aforementioned way of assessment was selected by 138 students (a percentage of $76.6 \%$ ), whereas the rest of them were given full access to the asynchronous education system, in order to study the material on which they would be examined in the end of the semester.

The assessment of the RFC intervention was based on the following materials and sources:

a) Two questionnaires that were completed by 138 students. The first questionnaire was during the second session, while in the first, the FC model had been thoroughly explained, so that students would be able to express their opinion on the basic elements of this type of education. The second questionnaire was during the last session. Completing the questionnaires was anonymous and elective, and therefore, the first one was completed by 132 students and the second one by 91 .

b) Diaries of the instructors, in which they kept detailed notes on the activities of every meeting on Zoom (such as the number of chat messages, the ratio of students/instructors time, etc.). Some of these data have also been mentioned in the previous section.

c) The available learning analytics of the asynchronous education system.

Firstly, we shall list some of the data of (b) and (c) before talking in detail about the data that emerged from the two questionnaires. All the meetings were attended by more than 105 students. In total, during the ten meetings held, 2,104 chat messages were registered. From the content analysis of these messages, it was found that 789 of them (a percentage of $37.5 \%$ ) was of administrative type (connection/sound/camera problems, questions regarding the breaks, and so on), 784 (37.3\%) were simple answers (yes/no or 
agree/disagree) to questions asked by students or instructors, while 530 messages (a percentage of $25.2 \%$ or around 55 messages on average in every meeting) concerned taking a position on the issues of the meetings, with a length of more than 5 lines. From the statistical data of the asynchronous education system, it was found that the times the users were connected were 8,304, the views were 70,022 and the total duration of using the system amounted to 2,797 hours. If we consider that the platform was used by all the students who had enrolled in the course, it can be found that, on average, approximately 46 connections, 500 views and 15.5 hours of use correspond to every student. As it can be observed, the hours of the connection and use of the platform of asynchronous education are at least equivalent or surpass the hours of lecturing in a traditional classroom.

As it has been mentioned, during the intervention two questionnaires were completed (initial and final), in which students expressed their thoughts on the course, most times in a 5-point Likert scale (the tables below present the opinions of the initial questionnaire in the pre columns and the ones of the final in the post column). Through two questions of the initial questionnaire, the extent of the students' familiarization with the FC was investigated. According to their answers, almost 1 in $3(28.8 \%)$ had attended a course using FC in the past, whereas almost the same percentage $(28.0 \%)$ state that they are well aware of the FC. The load of the course was one of the investigated parameters and, in the relevant question in the final questionnaire, only $9.9 \%$ of the students state that the load is much/very much heavier than in other courses.

Given that during the first course the functioning of the RFC and the conditions of the course had been explained in detail, it was considered interesting to ask the students both in the initial questionnaire (column pre) and in the final (column post) about those elements of the RFC that they expected to facilitate or those that finally facilitated attending the course and fulfilling their obligations (Table 1). Both from the percentages of agreement (Strongly agree / Agree) and based on the arithmetic means, some conclusions can be drawn regarding the elements of this particular RFC. Out of the 14 elements, only 3 show a slight decrease after the completion of the course, however, even in these cases the differences can be traced to the first decimal point. All the RFC elements have obtained rather high means, both in the initial and mostly in the final questionnaire, something that could be considered as a confirmation on the part of the students that these elements acted positively on the total learning experience they had had. 
Thanassis Karalis, Natassa Raikou

FLIPPING THE CLASSROOM REMOTELY: IMPLEMENTATION OF A FLIPPED

CLASSROOM COURSE IN HIGHER EDUCATION DURING THE COVID-19 PANDEMIC

\begin{tabular}{|c|c|c|c|c|c|c|c|c|c|c|c|c|c|c|}
\hline \multirow{3}{*}{ Element } & \multicolumn{6}{|c|}{ Pre } & \multicolumn{6}{|c|}{ Post } & \multirow{3}{*}{$\begin{array}{l}\text { Mean } \\
\text { Pre } \\
(1-5)\end{array}$} & \multirow{3}{*}{$\begin{array}{l}\text { Mean } \\
\text { Post } \\
(1-5)\end{array}$} \\
\hline & \multicolumn{2}{|c|}{$\begin{array}{c}\text { Strongly } \\
\text { disagree } \\
/ \\
\text { Disagree } \\
\end{array}$} & \multicolumn{2}{|c|}{$\begin{array}{c}\text { Strongly } \\
\text { agree } \\
/ \\
\text { Agree } \\
\end{array}$} & \multicolumn{2}{|c|}{ Undecided } & \multicolumn{2}{|c|}{$\begin{array}{l}\text { Strongly } \\
\text { disagree } \\
\text { / } \\
\text { Disagree } \\
\end{array}$} & \multicolumn{2}{|c|}{$\begin{array}{c}\text { Strongly } \\
\text { agree } \\
/ \\
\text { Agree } \\
\end{array}$} & \multicolumn{2}{|c|}{ Undecided } & & \\
\hline & $\mathrm{N}$ & $\%$ & $\mathrm{~N}$ & $\%$ & $\mathrm{~N}$ & $\%$ & $\mathrm{~N}$ & $\%$ & $\mathrm{~N}$ & $\%$ & $\mathrm{~N}$ & $\%$ & & \\
\hline $\begin{array}{l}\text { The opportunity to } \\
\text { watch a video/ppt } \\
\text { and study instead of } \\
\text { a lecture }\end{array}$ & 1 & 0.8 & 103 & 78.0 & 28 & 21.2 & 2 & 2.2 & 80 & 87.9 & 9 & 9.9 & 4.13 & 4.21 \\
\hline $\begin{array}{l}\text { The variety of the } \\
\text { educational material } \\
\text { has sparked my } \\
\text { interest }\end{array}$ & 1 & 0.8 & 121 & 91.7 & 10 & 7.6 & 1 & 1.1 & 82 & 90.1 & 8 & 8.8 & 4.27 & 4.34 \\
\hline $\begin{array}{l}\text { Better } \\
\text { understanding of the } \\
\text { subject }\end{array}$ & 0 & 0 & 115 & 87.1 & 17 & 12.9 & 1 & 1.1 & 75 & 82.4 & 15 & 16.5 & 4.20 & 4.09 \\
\hline $\begin{array}{l}\text { Enhancing the } \\
\text { cooperativity and } \\
\text { socialization }\end{array}$ & 2 & 1.5 & 94 & 71.2 & 36 & 27.3 & 2 & 2.2 & 74 & 81.3 & 15 & 16.5 & 4.07 & 4.22 \\
\hline $\begin{array}{l}\text { Enhancing the extent } \\
\text { of implication and } \\
\text { active participation } \\
\text { in the educational } \\
\text { process }\end{array}$ & 0 & 0 & 108 & 81.8 & 24 & 18.2 & 1 & 1.1 & 80 & 87.9 & 10 & 11.0 & 4.22 & 4.31 \\
\hline $\begin{array}{l}\text { Studying the } \\
\text { educational material } \\
\text { at my own pace and } \\
\text { time }\end{array}$ & 1 & 0.8 & 112 & 84.8 & 19 & 14.4 & 1 & 1.1 & 72 & 79.1 & 18 & 19.8 & 4.27 & 4.27 \\
\hline $\begin{array}{l}\text { Efficient use of } \\
\text { teaching time in the } \\
\text { classroom }\end{array}$ & 0 & 0 & 117 & 88.6 & 15 & 11.4 & 1 & 1.1 & 75 & 82.4 & 15 & 16.5 & 4.26 & 4.24 \\
\hline $\begin{array}{l}\text { Professor's } \\
\text { interaction with } \\
\text { students }\end{array}$ & 1 & 0.8 & 117 & 88.6 & 14 & 10.6 & 1 & 1.1 & 85 & 93.4 & 5 & 5.5 & 4.37 & 4.45 \\
\hline $\begin{array}{l}\text { Interaction with } \\
\text { fellow students }\end{array}$ & 2 & 1.5 & 99 & 75.0 & 31 & 23.5 & 1 & 1.1 & 74 & 81.3 & 16 & 17.6 & 4.10 & 4.23 \\
\hline $\begin{array}{l}\text { Personal satisfaction } \\
\text { and the feeling of } \\
\text { self-realization }\end{array}$ & 2 & 1.5 & 111 & 84.1 & 19 & 14.4 & 1 & 1.1 & 76 & 83.5 & 14 & 15.4 & 4.20 & 4.22 \\
\hline $\begin{array}{l}\text { The opportunity for } \\
\text { critical thinking and } \\
\text { development of } \\
\text { ideas }\end{array}$ & 2 & 1.5 & 119 & 90.2 & 11 & 8.3 & 1 & 1.1 & 83 & 91.2 & 7 & 7.7 & 4.36 & 4.44 \\
\hline $\begin{array}{l}\text { The use of } \\
\text { technology in an } \\
\text { innovative way }\end{array}$ & 0 & 0.0 & 115 & 87.1 & 17 & 12.9 & 1 & 1.1 & 77 & 84.6 & 13 & 14.3 & 4.30 & 4.31 \\
\hline $\begin{array}{l}\text { The advisory and } \\
\text { guiding role of the } \\
\text { professor while } \\
\text { assignments are } \\
\text { carried out in the } \\
\text { classroom }\end{array}$ & 1 & 0.8 & 122 & 92.4 & 9 & 6.8 & 1 & 1.1 & 84 & 92.3 & 6 & 6.6 & 4.47 & 4.43 \\
\hline
\end{tabular}


In exactly the same way, the students were asked about some parameters which could serve as deterrents to attending the course and could have a negative impact on their participation in the course (Table 2). Out of the 9 parameters, an increase in the arithmetic means is observed in four, however, like in the case of elements, this is restricted to the first decimal point. Moreover, while in the case of elements the fluctuations vary between 4.07 and 4.45 , in the case of deterrents, the fluctuations show a lower range (from 2.87 to 3.80), something that leads us to the conclusion that the deterrents are not so restrictive, at least in relation to the motivation which can be indicated by the elements.

Table 2: Deterrents to attending Remote Flipped Classroom

\begin{tabular}{|c|c|c|c|c|c|c|c|c|c|c|c|c|c|c|}
\hline \multirow{3}{*}{ Deterrent } & \multicolumn{6}{|c|}{ Pre } & \multicolumn{6}{|c|}{ Post } & \multirow{3}{*}{$\begin{array}{l}\text { Mean } \\
\text { Pre } \\
(1-5)\end{array}$} & \multirow{3}{*}{$\begin{array}{r}\text { Mean } \\
\text { Post } \\
(1-5)\end{array}$} \\
\hline & \multicolumn{2}{|c|}{$\begin{array}{c}\text { Strongly } \\
\text { disagree } \\
/ \\
\text { Disagree }\end{array}$} & \multicolumn{2}{|c|}{$\begin{array}{c}\text { Strongly } \\
\text { agree } \\
/ \\
\text { Agree }\end{array}$} & \multicolumn{2}{|c|}{ Undecided } & \multicolumn{2}{|c|}{$\begin{array}{c}\text { Strongly } \\
\text { disagree } \\
/ \\
\text { Disagree }\end{array}$} & \multicolumn{2}{|c|}{$\begin{array}{c}\text { Strongly } \\
\text { agree } \\
/ \\
\text { Agree }\end{array}$} & \multicolumn{2}{|c|}{ Undecided } & & \\
\hline & $\mathrm{N}$ & $\%$ & $\mathrm{~N}$ & $\%$ & $\mathrm{~N}$ & $\%$ & $\mathrm{~N}$ & $\%$ & $\mathrm{~N}$ & $\%$ & $\mathrm{~N}$ & $\%$ & & \\
\hline $\begin{array}{l}\text { Reduced } \\
\text { interaction } \\
\text { between professor } \\
\text { and students }\end{array}$ & 19 & 14.4 & 86 & 65.2 & 27 & 20.5 & 20 & 22.0 & 53 & 58.2 & 18 & 19.8 & 3.78 & 3.57 \\
\hline $\begin{array}{l}\text { Reduced } \\
\text { interaction among } \\
\text { students }\end{array}$ & 10 & 7.6 & 86 & 65.2 & 36 & 27.3 & 16 & 17.6 & 57 & 62.6 & 18 & 19.8 & 3.89 & 3.76 \\
\hline $\begin{array}{l}\text { Students' reduced } \\
\text { knowledge about } \\
\text { the tools of remote } \\
\text { education }\end{array}$ & 12 & 9.1 & 86 & 65.2 & 34 & 25.8 & 13 & 14.3 & 57 & 62.6 & 21 & 23.1 & 3.76 & 3.80 \\
\hline $\begin{array}{l}\text { Difficulty in using } \\
\text { the } \\
\text { communication } \\
\text { platform }\end{array}$ & 13 & 9.8 & 87 & 65.9 & 32 & 24.2 & 18 & 19.8 & 51 & 56.0 & 22 & 24.2 & 3.79 & 3.55 \\
\hline $\begin{array}{l}\text { Poor quality of } \\
\text { educational } \\
\text { material }\end{array}$ & 38 & 28.8 & 71 & 53.8 & 23 & 17.4 & 41 & 45.1 & 45 & 49.5 & 5 & 5.5 & 3.37 & 3.03 \\
\hline $\begin{array}{l}\text { Lack of } \\
\text { encouragement on } \\
\text { the part of the } \\
\text { professor }\end{array}$ & 57 & 43.2 & 56 & 42.4 & 19 & 14.4 & 45 & 49.5 & 40 & 44.0 & 6 & 6.6 & 2.87 & 2.79 \\
\hline $\begin{array}{l}\text { Workload outside } \\
\text { the scheduled } \\
\text { classes at } \\
\text { university }\end{array}$ & 25 & 18.9 & 70 & 53.0 & 37 & 28.0 & 24 & 26.4 & 44 & 48.4 & 23 & 25.3 & 3.52 & 3.32 \\
\hline $\begin{array}{l}\text { Lack of time to } \\
\text { study at home }\end{array}$ & 27 & 20.5 & 77 & 58.3 & 28 & 21.2 & 19 & 20.9 & 57 & 62.6 & 15 & 16.5 & 3.53 & 3.66 \\
\hline $\begin{array}{l}\text { The professor's } \\
\text { "absence" during } \\
\text { studying from } \\
\text { home through the } \\
\text { virtual classroom }\end{array}$ & 35 & 26.5 & 65 & 49.2 & 32 & 24.2 & 28 & 30.8 & 52 & 57.1 & 11 & 12.1 & 3.30 & 3.43 \\
\hline
\end{tabular}


From the data of Tables 1 and 2 it can be established that the students adopt a very positive stance on the various elements of RFC, both before and after the intervention, and the deterrents do not constitute negative predispositions. This conclusion is validated by the data of Table 3, where students rate from 1 to 5 the extent to which their expectations of the implementation of RFC were finally met. As shown by the data listed in Table 3, a percentage of $86.9 \%$ rate between the two higher points of the scale (4 and $5)$, whereas only 2 students rate the fulfillment of their expectations with a 2.

Table 3: Degree of expectation's fulfillment

\begin{tabular}{|l|c|c|}
\hline Grade & $\mathbf{N}$ & $\mathbf{\%}$ \\
\hline 1 & 0 & 0.0 \\
\hline 2 & 2 & 2.2 \\
\hline 3 & 10 & 10.9 \\
\hline 4 & 41 & 45.1 \\
\hline 5 & 38 & 41.8 \\
\hline Total & 91 & 100.0 \\
\hline
\end{tabular}

Afterwards, given the students' experience from attending the RFC, they were asked to evaluate FC in general, regarding its possible implementation after returning to face-toface teaching upon the end of the pandemic, stating in an open-ended question why they find FC effective in tertiary education and which are the advantages and disadvantages in relation to traditional classroom.

Table 4: Comparison of flipped classroom in relation to traditional classroom

\begin{tabular}{|l|c|}
\hline & References \\
\hline Interaction and increased participation of students & 28 \\
\hline Better relationship and communication between professors and students & 18 \\
\hline Choosing the time and pace of studying on the part of the students & 16 \\
\hline Better understanding of the content & 12 \\
\hline Development of critical thinking & 11 \\
\hline Multifaceted approach of the content (material, work in groups, etc.) & 10 \\
\hline Activation of the students' interest & 7 \\
\hline Innovative teaching exploitation of the possibilities provided by technology & 5 \\
\hline Total & 107 \\
\hline
\end{tabular}

The above findings can be confirmed by the data of Table 5. It is a presentation of the students' answers to the question they were asked, i.e. to rate the two ways of teaching using a scale $1-10$. 
Table 5: Rating of flipped vs. traditional classroom

\begin{tabular}{|l|c|c|c|c|}
\hline Rating & \multicolumn{2}{|c|}{ Flipped } & \multicolumn{2}{c|}{ Traditional } \\
\hline & $\mathrm{N}$ & $\%$ & $\mathrm{~N}$ & $\%$ \\
\hline 1 & 0 & 0.0 & 3 & 3.3 \\
\hline 2 & 1 & 1.1 & 2 & 2.2 \\
\hline 3 & 1 & 1.1 & 2 & 2.2 \\
\hline 4 & 3 & 3.3 & 10 & 11.0 \\
\hline 5 & 3 & 3.3 & 14 & 15.3 \\
\hline 6 & 4 & 4.4 & 20 & 22.0 \\
\hline 7 & 17 & 18.6 & 8 & 8.8 \\
\hline 8 & 13 & 14.3 & 17 & 5.7 \\
\hline 9 & 24 & 26.4 & 5 & 11.0 \\
\hline 10 & 25 & 27.5 & 10 & 100.0 \\
\hline Total & 91 & 100.0 & 91 & \\
\hline
\end{tabular}

As indicated by the data of Table 5, significant differences can be found when comparing the ways of teaching. As it can be observed, more than one in four students $(27.5 \%)$ give the highest score of the scale (10) to the FC, compared to almost one in ten $(11.0 \%)$ who give traditional teaching the same score. The FC is rated with the highest points ( 9 and 10 ) by more than half of the students $(53.9 \%)$, compared to $16.5 \%$ for the traditional. In addition, some differences can be found at the sum of the percentages for scores lower than 5, in the case of the FC it amounts to 5.5\%, while in the traditional the equivalent percentage is almost triple. As far as the arithmetic mean is concerned, in the case of traditional it is $6.37 \%$, while in the case of FC is it 8.18 (i.e. increased by almost $30 \%$ ).

A final source of data that was used for the assessment of the course, apart from the questionnaires that were given to the students, are the official data of the Quality Assurance Unit of the University of Patras. At the University of Patras, in the end of every semester, students evaluate instructors and courses. In Table 6 the arithmetic means are listed (the highest being a 5) in specific questions/items which are related to the way of teaching the lesson, i.e. the RFC. It can be established from the data of Table 6 that the educational material was considered as totally adequate, concerning both its quality elements, and its contribution to understanding the content. We consider this element rather significant for the RFC, since students think that they can understand the content of the platforms' material and, therefore, attend the online meetings well-prepared for the participatory activities. This may explain the element referred to in the previous section based on the instructors' diaries, i.e. that only a very small amount of the time of the synchronous education, only $15 \%$, concerned responding to the students' queries. 


\begin{tabular}{|l|c|}
\hline \multicolumn{1}{|c}{ Table 6: Student's evaluation of the course } \\
\hline Question/Item & Mean \\
\hline Do you find the remote education platforms which were used appropriate? & 4.41 \\
\hline $\begin{array}{l}\text { What rating would you give to the quality of the content of the additional } \\
\text { educational material on eclass? }\end{array}$ & 4.65 \\
\hline $\begin{array}{l}\text { To what extent was the contribution of the additional educational material of } \\
\text { the eclass important for the comprehension of the courses? }\end{array}$ & 4.66 \\
\hline Did the professor explain the importance and the goals of the course to you? & 4.76 \\
\hline Were the professor's lectures comprehensible? & 4.78 \\
\hline $\begin{array}{l}\text { Do you think that the content organization and the cohesion of the lectures } \\
\text { were satisfactory throughout the progress of the courses? }\end{array}$ & 4.66 \\
\hline Did the way of teaching spark your interest for the course? & 4.34 \\
\hline Did the professor develop a cooperation with his/her students? & 4.78 \\
\hline
\end{tabular}

Source: Official Information System - Quality Assurance Unit, University of Patras.

In the questionnaires of the Quality Assurance Unit which are completed by the students, there is an open-ended question where they may express their opinion on the course. Below we cite some of the most characteristic responses which concern the type of the course, i.e. the RFC.

It was a rather interesting and original course, since it was conducted in a different way. It was a new experience and I would very much like other courses to be conducted in this way.

Interesting way of teaching. It leads us to new paths of teaching.

I think that the way of teaching of this particular course is very interesting, because it constitutes an innovative evolution for the learning process. More specifically, through the flipped classroom we are provided with the opportunity both to cooperate among us and to make the course more comprehensible.

It was very functional, despite the difficult circumstances of this period.

One of the most interesting courses of the semester. The elements that make it interesting are the approach method of the new knowledge, i.e. the flipped classroom (which I had never before come into contact with) and also the discussion which is carried out in order to process the new information that we are called to assimilate after studying the new material.

The fact that we studied on our own, at our own time, helped us to better understand the topics. The videos you have used were very interesting.

At this particular course we have used a rather facilitative way for us, students, the flipped classroom. It was the best way of teaching, in my opinion, that I have ever seen. I would suggest that it should be extended to all the other courses.

\section{Conclusions}

This paper outlined an experimental implementation of what we called Remote Flipped Classroom, during the COVID-10 pandemic. In fact, this implementation was twofold; on the one hand, we aimed at investigating the implementation of the flipped classroom in 
distance education mode, and on the other hand, the dynamic of the flipped classroom itself in circumstances of normality. As for the function of the RFC, according to the data presented, it can be established that the students spent more time studying the material compared to the time spent during a traditional lecture, while the time of all online meetings (synchronous part of education) was devoted to participatory and engaging activities for the students.

All the elements of the RFC (indicatively: better allocation of time, enhancement of cooperativeness, active participation, interaction among students and between students and instructors, opportunity to develop critical thinking) were considered as functional and received positive views from the students. This motivation which was due to these particular elements resulted in presenting a reduced impact of the possible deterrents (indicatively: workload, lack of time to study at home). Almost 9 in 10 students mention that their expectations were fulfilled to a significant extent, while at the official evaluation of the course by the Quality Assurance Unit of the University of Patras, the students' scores for all the parameters concerning the mode of the course, fell in the higher $20 \%$ of the rating scale. Therefore, it could be concluded that the RFC model worked effectively and upon returning to normality, its use from distance education systems could be considered, so that the provided education could become more effective and promote the active participation and engagement of the students.

On the other hand, the exposure of students to this new experience of organizing the course, gave them the opportunity to think on the utility of the FC and on the traditional, in-person education, upon returning to normality. What can be concluded from the relevant data which were presented is that students are able to take on responsibility to a great extent to study the material, which constitutes a basic prerequisite for the successful implementation of the FC approaches, whereas they adopted a very positive stance towards their active participation and towards activities that move beyond the logic of traditional lecture. The students evaluated this mode of the course as approximately $30 \%$ better in comparison to the traditional mode, they express clearly more positive views about it and they list a series of advantages which make it a more attractive approach to learning. According to the aforementioned, we think that a further investigation of the implementation possibilities of both the RFC and the FC, should be the priorities of the investigation in the field of Higher Education Pedagogy. As it can be concluded from the data presented here, these modes of teaching organization may function effectively towards the renewal of in-person teaching and act restrictively to the mechanistic penetration of the ICTs into higher education, by effectively combining the possibilities of e-learning and the active participation of students.

\section{Conflict of Interest Statement}

The authors declare no conflicts of interest 


\begin{abstract}
About the Authors
Thanassis Karalis is Professor of Lifelong Learning and Adult Education in the Department of Educational Science and Early Childhood Education at the University of Patras. He is Director of the Laboratory of Pedagogical Research and Lifelong Education, member of the Quality Assurance Unit and coordinator of the Center for Teaching and Learning at the University of Patras. His research interests include adult and higher education, planning and evaluation of non-formal education programs, distance education and e-learning.

Dr. Natassa Raikou is Teaching Staff in Adult and Higher Education at the University of Patras and Tutor-Counselor at the Hellenic Open University. She has a long teaching experience on higher education and teachers training programs, with publications in international and Greek journals. She is also member of several International and Greek scientific networks. Her research interests include adult education, university pedagogy, transformative learning, emerging adulthood and critical reflection.
\end{abstract}

\title{
References
}

Abeysereka, L., \& Dawson, P. (2014). Motivation and cognitive load in the flipped classroom: definition, rationale and a call for research, Higher Education Research and Development, 34(1), 1-14.

Baker, J. (2000). The "classroom flip": Using web course management tools to become the guide by the side. Paper presented at the Annual Technology Conference, Council for Christian Colleges \& Universities, Azusa Pacific University, Azusa, California.

Charissi, A., Tympa, E., \& Karavida, V. (2020). Impact of the COVID-19 disruption on University student's perceptions and behavior, European Journal of Education Studies, 7(1), 222-238.

Collado-Valero, J., Rodriquez-Infante, G., Romero-Gonzalez, M., Gamboa-Ternero, S., Navarro-Soria, I., \& Lavigne-Cervan, R. (2021). Flipped Classroom: Active Methodology for Sustainable Learning in Higher Education during Social Distancing Due to COVID-19, Sustainability, 13, 1-19.

Kamarianos, I., Adamopoulou, A., Lambropoulos, H., \& Stamelos, G. (2020). Towards an understanding of university students' response in times of pandemic crisis (COVID-19), European Journal of Education Studies, 7(7), pp. 20-40.

Karalis, T., \& Koutsonikos, G. (2003). Issues and Challenges in Organizing Web-based Courses for Adults, Themes in Education, 4(2), 177-188.

Karalis, T., \& Raikou, N. (2020). Teaching in times of COVID-19: Inferences and Implications for Higher Education Pedagogy, International Journal of Academic Research in Business E Social Sciences, 10(5), 479-493.

Karalis, T., Sotiropoulos, L., \& Kampeza, M. (2007). La contribution de l'éducation tout au long de la vie et de l'anthropologie dans la préparation professionnelle des enseignants : réflexions théoriques, Skholê, hors série 1, 149-155. 
Konstantopoulou, G., \& Raikou, N. (2020). Clinical Evaluation of Depression on University Students during Quarantine due to COVID-19 Pandemic, European Journal of Public Health Studies, 3(1), 1-8.

Latorre-Cosculluela, C. Suárez, C. Quiroga, S., Sobradiel-Sierra, N. Lozano-Blasco,

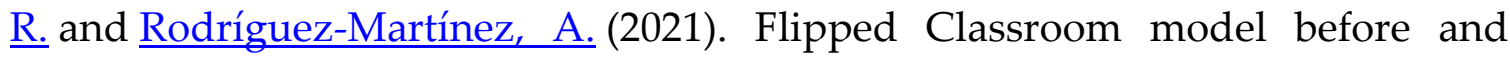
during COVID-19: using technology to develop 21st century skills, Interactive Technology and Smart Education, ahead-of-print. https://doi.org/10.1108/ITSE-082020-0137.

Liodaki, N., \& Karalis, T. (2013). Educational Experiences and Transformative Learning in Higher Education in Greece: A Case Study with Student Teachers, International Journal of Education, 5(2), 75-85.

Pandya, B., Patterson, L., \& Yun Cho, B. (2021). Pedagogical transitions experienced by higher education faculty members-"Pre-Covid to Covid", Journal of Applied Research Higher Education, https://www.emerald.com/insight/content/doi/10.1108/JARHE-01-20210028/full/html.

Panther, L., Allee-Herndon, K.A., Perrotta, K., \& Cannon, S. (2021). I Can Tell You Stories: Teacher Education during Educational Disruption, The Teacher Educator, https://www.tandfonline.com/doi/full/10.1080/08878730.2021.1918302.

Pavlis-Korres, M., Karalis, T., Leftheriotou, P., \& Barriocanal, E.G. (2009). Integrating Adults' Characteristics and the Requirements for their Effective Learning in an eLearning Environment, $2^{\text {nd }}$ World Summit on the Knowledge Society, Chania, Greece, 16-18 September 2009. In M. D. Lytras, P.O. de Pablos, E. Damiani, D. Avison, A. Neave, \& D.G. Horner (eds.), 2009, Best Practices for the Knowledge Society: Knowledge, Learning, Development and Technology for All (570-584). Berlin: Springer.

Pavlis Korres, M. (2021). Enhancing Students' Online Experience: Best educational practices unveiled by the mouse in the presence of a cat. In L. Kyei-Blankson, E. Ntuli, \& J. Blankson (Eds.) Revealing Inequities in Online Education During Global Crises (pp. 420-446). USA: IGI-GLOBAL.

Plota, D., \& Karalis, T. (2019). Organization and implementation of a Flipped Classroom course in the Greek University context, Educational Journal of the University of Patras UNESCO Chair, 6(2), 53-61.

Raikou, N. (2012). Can University Be a Transformative Environment? Fostering Critical Reflection Through Art in Higher Education, Journal of Literature and Art Studies, 2(3), 416-421.

Raikou, N., \& Karalis, T. (2011). Exploring the potential of Transformative Learning in Higher Education: the development of students' critical thinking through aesthetic experience, $9^{\text {th }}$ International Conference on Transformative Learning, Athens, 2829 May 2011. In M. Alhadeff-Jones, \& A. Kokkos (eds.), 2011, Transformative Learning in Time of Crisis: Individual and Collective Challenges (261-267). Athens: Columbia University and Hellenic Open University. 
Raikou, N., Karalis, T., \& Ravanis, K. (2017). Implementing an Innovative Method to Develop Critical Thinking Skills in Student Teachers, Acta Didactica Napocensia, 10(2), 21-30.

Raikou, N., Kaltsidis, C., Kedraka, K., Karalis, T. (2020). Teaching in Times of COVID-19 Pandemic in Two Peripheral Greek Universities: Lessons Learned from Students' Experiences and Opinions, Research Journal of Education, 6(8), 135-143.

Rakitzi, K., Botsoglou, K., \& Roussakis, ؟. (2020). Applying the Flipped Classroom Model to Higher Education: students "take the floor", Open Education, 16(1), 132-144.

Strayer, J. (2007). The effects of the classroom flip on the learning environment: A comparison of learning activity in a traditional classroom and a flip classroom that used an intelligent tutoring system. Unpublished doctoral dissertation, The Ohio State University, Columbus.

UNESCO Institute for Statistics Data (2021, June 3). COVID-19 Impact on Education. Retrieved from: https://en.unesco.org/covid19/educationresponse. 
Creative Commons licensing terms

Authors will retain the copyright of their published articles agreeing that a Creative Commons Attribution 4.0 International License (CC BY 4.0) terms will be applied to their work. Under the terms of this license, no permission is required from the author(s) or publisher for members of the community to copy, distribute, transmit or adapt the article content, providing a proper, prominent and unambiguous attribution to the authors in a manner that makes clear that the materials are being reused under permission of a Creative Commons License. Views, opinions and conclusions expressed in this research article are views, opinions and conclusions of the author(s). Open Access Publishing Group and European Journal of Open Education and E-learning Studies shall not be responsible or answerable for any loss, damage or liability caused in relation to/arising out of conflict of interests, copyright violations and inappropriate or inaccurate use of any kind content related or integrated on the research work. All the published works are meeting the Open Access Publishing requirements and can be freely accessed, shared, modified, distributed and used in educational, commercial and non-commercial purposes under a Creative Commons Attribution 4.0 International License (CC BY 4.0). 